\title{
Pengembangan Bahan Ajar Matematika Berbasis Scientific yang Berorientasi pada Kemampuan Berpikir Kritis Matematis Siswa
}

\author{
Iik Nurhikmayati1 ${ }^{*}$ dan M. Gilar Jatisunda ${ }^{2}$ \\ Universitas Majalengka \\ Jalan K.H Abdul Halim No 103, Majalengka, Jawa Barat, Indonesia \\ 1*ik.nurhikmayati@gmail.com \\ 2djatisunda11243@gmail.com
}

Artikel diterima: 12-10-2018, direvisi: 19-01-2019, diterbitkan: 31-01-2019

\begin{abstract}
Abstrak
Penelitian ini bertujuan menghasilkan bahan ajar matematika berbasis scientific untuk siswa SMP yang memenuhi kriteria valid, praktis, dan efektif yang berorientasi pada kemampuan berpikir kritis matematis. Jenis penelitian ini adalah penelitian dan pengembangan (Research and Development, $R \& D$ ) menurut Borg \& Gall yang terdiri atas tiga langkah utama yaitu studi pendahuluan, desain produk serta pengembangan dan evaluasi. Subjek penelitian ini adalah siswa kelas VIII SMPN 1 Palasah dengan Instrumen berupa instrumen tes kemampuan berpikir kritis, lembar validasi para ahli, lembar penilaian kepraktisan dan angket respon siswa. Hasil penelitian menunjukkan bahwa bahan ajar matematika berbasis scientific yang dikembangkan telah memenuhi kriteria valid, praktis dan efektif ditinjau dari kemampuan berpikir kritis matematis. Uji perbedaan keefektifan ini menggunakan uji multivariat Hotteling's Trace dan uji perbandingan keefektifan menggunakan uji statistik univariat between group yang menunjukkan bahwa bahan ajar berbasis scientific yang digunakan kelas uji coba lebih efektif dibandingkan bahan ajar buku paket biasa yang digunakan pada kelas kontrol.

Kata kunci: bahan ajar, kemampuan berpikir kritis matematis, scientific.
\end{abstract}

\section{Development of Mathematic Teaching Material Based on Scientific Oriented to the Mathematical Critical Thinking Ability of Student}

\begin{abstract}
This study aims to produce scientific-based mathematics worksheets for junior high school students that meet the criteria of valid, practical, and effective oriented mathematical critical thinking skills. This is a research and development ( $R$ \& D) according to Borg \& Gall which consists of three main steps, namely preliminary study, product design and development and evaluation. The subjects of this study were the eighth grade students of SMPN 1 Palasah with instruments in the form of critical thinking ability tests, expert validation sheets, practicality assessment sheets and student response questionnaires. The effectiveness of teaching materials is shown based on the percentage of the number of students who are at least in the good category at $95.8 \%$ and this effectivesness test uses multivariate Hotteling's Trace test adn comparison of effectiveness test using univariate statistical test between groups and the result show that the teaching materials of scientific-based worksheets are more effective than teaching materials for general textbooks.

Keyword: teaching material, mathematical critical thinking ablity, scientific.
\end{abstract}

Mosharafa: Jumal Pendidikan Matematika

Volume 8, Nomor 1, Januari 2019

Copyright $\odot 2019$ Mosharafa: Jurnal Pendidikan Matematika 


\section{Pendahuluan}

Kemampuan berpikir kritis merupakan salah satu dari kemampuan berpikir tingkat tinggi atau disebut high-order mathematical thinking skill. Dalam kegiatan berpikir seperti ini seorang siswa dituntut untuk memiliki keterampilan berpikir, keaslian ide, fleksibilitas serta keluwesannya dalam mencari solusi dari masalah yang dihadapi. Pada saat siswa dihadapkan pada masalah matematis nonrutin, rumit, tidak dikenal maka siswa akan berpikir untuk menemukan solusi dari masalah yang dihadapi. Siswa akan berpikir dengan menduga, mencoba-coba, memprediksi, serta mencari rumusan sederhana yang kemudian bisa dibuktikan kebenaran dari solusi yang diperolehnya. Dengan memiliki kemampuan berpikir kritis, siswa dapat mengevaluasi setiap kebenaran dari penyelesaian masalah tersebut sehingga dapat mendapatkan solusi yang tepat.

Fisher (2009) menyatakan bahwa berpikir kritis adalah menjelaskan apa yang dipikirkan. Belajar untuk berpikir kritis berarti: belajar bagaimana bertanya, kapan bertanya, apa pertanyaannya, bagaimana nalarnya, kapan menggunakan penalaran dan metode penalaran apa yang dipakai. Belajar bertanya akan menuntun seseorang untuk mengevaluasi setiap kebenaran yang ada berdasarkan bukti. Artinya berpikir kritis akan memungkinkan siswa dapat memecahkan masalah yang dihadapi dengan caranya sendiri.

Namun kenyataannya kemampuan berpikir kritis masih belum berkembang secara optimal. Tidak banyak guru yang secara kreatif mengembangkan kemampuan berpikir kritis selama proses pembelajaran. Seperti yang diungkapkan kritikus Jacqueline dan Brookes (Santrock, 2007), sedikit sekolah yang mengajarkan siswanya berpikir kritis. Sekolah justru mendorong siswanya untuk pandai dalam menghafal dan memberi jawaban yang benar tanpa memikirkan ulang asal mula jawaban yang diperoleh. Kurang optimalnya pengembangan kemampuan berpikir kritis tersebut mengakibatkan kemampuan kritis matematis siswa menjadi rendah.

Hal tersebut terbukti dari penelitian yang dilakukan Anitasari (2015) yang menyatakan bahwa hasil evaluasai yang dilakukannya terhadap tes kemampuan berpikir kritis siswa SMPN 1 Wates belum maksimal yakni hanya mencapai nilai ratarata 69,00. Berdasarkan hasil penelitian Syahbana (2012) menunjukkan bahwa masih rendahnya rata-rata kemampuan berpikir kritis matematis siswa SMP. Nilai rata-rata kemampuan berpikir kritis matematis siswa SMP hanya 68, artinya dalam skala 0-100, nilai ini termasuk dalam kategori cukup.

Berdasarkan fakta di lapangan yang bertolak belakang dengan pentingnya kemampuan berpikir kritis, diperlukan adanya upaya mengembangkan kemampuan berpikir kritis siswa sejak dini. Salah satu upaya mengembangkan kemampuan berpikir kritis adalah penggunaan bahan ajar yang berorientasi pada kemampuan tersebut.

Bahan ajar merupakan komponen yang harus ada dalam proses pembelajaran. Bahan ajar adalah suatu komponen yang harus dikaji, dicermati, dipelajari dan dijadikan bahan materi yang akan dikuasai oleh siswa dan sekaligus dapat 
memberikan pedoman untuk mempelajarinya (Hernawan, dkk, 2012). Bahan ajar yang digunakan guru hendaknya dapat menuntun siswa untuk dapat mencapai standar kompetensi yang diinginkan. Bahan ajar yang digunakan harus sesuai dengan karakteristik sasaran (Depdiknas, 2008).

Pentingnya bahan ajar sebagai pedoman dalam proses pembelajaran bertolak belakang dengan keadaan yang ada. Bahan ajar yang digunakan di sekolah-sekolah saat ini terkesan kurang menarik, tidak inovatif dan masih belum dapat memfasilitasi pencapaian kemampuan matematis siswa, salah satunya pada kemampuan berpikir kritis matematis. Dalam pengembangan bahan ajar, metode atau pendekatan pembelajaran menjadi satu kesatuan yang harus disesuaikan selama proses pembelajaran berlangsung. Dalam kurikulum 2013, pendekatan pembelajaran yang digunakan adalah pendekatan scientific atau pendekatan berbasis keilmuan yang meliputi kegiatan mengamati, menanya, menalar, mencoba, dan membentuk jejaring. Penerapan pendekatan scientific diyakini dapat mengembangkan keterampilan berpikir tingkat tinggi siswa yang diakibatkan karena siswa diajak untuk berproses aktif menemukan sendiri pengetahuannya dari pengalaman belajar yang dilakukan. Beberapa penelitian relevan telah mengungkap kondisi permasalahan di dalam kelas dengan pembelajaran scientific digunakan sebagai solusi permasalahan tersebut (Ramziah, 2016; Razak \& Kamaruddin, 2018; Maryati, 2018).

Berdasarkan uraian tersebut, tujuan penelitian ini adalah mengembangkan bahan ajar matematika berbasis scientific dimana komponen, prinsip dan karakteristik pendekatan scientific dapat digunakan sebagai upaya dalam mengembangkan kemampuan berpikir kritis matematis siswa SMP pada materi Pythagoras dan untuk mendeskripsikan kualitas bahan ajar ditinjau dari aspek kevalidan, kepraktisan dan keefektifan.

\section{Metode}

Jenis penelitian ini adalah penelitian dan pengembangan (R\&D) dengan model pengembangan mengadopsi dari model pengembangan Borg \& Gall (1983). Model pengembangan ini terdiri dari 10 tahapan yang dapat dibagi menjadi tiga tahap, yaitu tahap studi pendahuluan, tahap desain produk serta tahap pengembangan dan evaluasi.

Penelitian ini dilaksanakan di SMPN 1 Palasah Kabupaten Majalengka Jawa Barat dari bulan Februari hingga September 2018. Subjek uji coba terbatas melibatkan 9 siswa yang memiliki kategori kemampuan tinggi, sedang dan rendah. Sedangkan subjek uji coba lapangan melibatkan dua kelas yakni kelas VIII B sebagai kelas uji coba yang menggunakan bahan ajar yang dikembangkan dan kelas VIII D sebagai kelas kontrol yang menggunakan buku paket matematika. Jumlah siswa pada kelas uji coba adalah 24 siswa dan jumlah siswa pada kelas kontrol adalah 24 siswa.

Instrumen dalam penelitian terdiri dari lima jenis yaitu lembar validasi, lembar penilaian kepraktisan bahan ajar oleh guru dan siswa, lembar observasi, anget respon siswa serta tes kemampuan berpikir kritis matematis siswa untuk melihatan keefektifan bahan ajar. Analisis data hasil 
penelitian dibagi empat kriteria yaitu analisis kevalidan, analisis kepraktisan, analisis keefektifan, dan analisis angket respon siswa. Lembar validasi bahan ajar disusun berdasarkan kisi-kisi instrumen sebagai berikut.

Tabel 1.

Kisi-Kisi Angket Kevalidan Bahan Ajar

\begin{tabular}{|ccc|}
\hline Aspek & Komponen & Indikator \\
\hline Materi & Kelayakan Isi & kesesuaian materi (8 butir pernyataan) \\
\cline { 2 - 3 } & & Kesesuaian dengan orientasi berpikir kritis (5 butir pernyataan) \\
\hline \multirow{3}{*}{ Media } & $\begin{array}{c}\text { Kelayakan pendekatan } \\
\text { scientific }\end{array}$ & $\begin{array}{c}\text { Kesesuaian penerapan tahapan scientific dengan tujuan pembelajaran (6 butir } \\
\text { pernyataan) }\end{array}$ \\
\cline { 2 - 3 } & Kelengkapan penyajian & Prakata, daftar isi, petunjuk LKS, latihan, daftar pustaka (5 butir pernyataan) \\
\cline { 2 - 3 } & Kelayakan kebahasaan & Kaidah bahasa, kalimat, istilah dan lambang (5 butir pernyataan) \\
\cline { 2 - 3 } & Kelayakan kegrafikan & Sampul LKS (2 butir pernyataan) \\
\cline { 2 - 3 } & & Isi buku (3 butir pernyataan)
\end{tabular}

Skor rata-rata yang diperoleh dari hasil uji validasi kemudian dianalisis secara deskriptif kualitatif. Data berupa hasil uji validasi selanjutnya dirujuk pada tabel kategori konversi kevalidan bahan ajar menurut Azwar (2015) seperti pada tabel berikut.

Tabel 2.

Kategori Konversi Data Hasil Uji Validasi

\begin{tabular}{|cc|}
\hline Interval Skor & Kategori \\
\hline$x>\bar{X}_{L}+1,8 S b_{i}$ & Sangat Valid \\
\hline $\bar{X}_{l}+0,6 S b_{i}<x<\bar{X}_{l}+1,8 S b_{i}$ & Valid \\
\hline $\bar{X}_{l}-0,6 S b_{i}<x<\bar{X}_{l}+0,6 S b_{i}$ & Cukup Valid \\
\hline $\bar{X}_{l}-1,8 S b_{i}<x<\bar{X}_{l}-0,6 S b_{i}$ & Kurang Valid \\
\hline$x<\bar{X}_{\iota}-1,8 S b_{i}$ & Tidak Valid
\end{tabular}

Keterangan:

$$
\begin{aligned}
\bar{X}_{l}= & \text { Rata-rata skor ideal } \\
& 1 / 2 \text { (skor maks }+ \text { skor min) } \\
S b_{i}= & \text { Simpangan baku ideal } \\
& 1 / 6 \text { (skor maks }- \text { skor min) } \\
x= & \text { Skor aktual }
\end{aligned}
$$

Analisis kepraktisan bahan ajar diperoleh dari data hasil penilaian dari guru dan siswa serta hasil pengamatan pembelajaran pada uji coba terbatas dan uji coba lapangan. Indikator yang digunakan pada angket kepraktisan bahan ajar adalah tampilan dan kemudahan pengguna. Adapun angket kepraktisan untuk siswa ditambah dengan indikator respon. Data hasil penilaian guru dan siswa selanjutnya dikonversi menjadi lima kategori kepraktisan yaitu: sangat praktis, praktis, cukup praktis, kurang praktis, dan tidak praktis. Perhitungan konversi tersebut dilakukan dengan menggunakan formula pada Tabel 2.

Analisis keefektifan bahan ajar dalam penelitian ini ditinjau dari hasil tes kemampuan berpikir kritis matematis melalui pretest dan postest kelas uji coba dan kelas kontrol pada uji coba lapangan. Indikator berpikir kritis yang digunakan dalam penelitian ini yaitu (1) memusatkan diri pada satu tema/pernyataan; (2) menganalisis, menjelaskan pertanyaan, jawaban dan argumen; (3) mendeduksi dan mengindukasi serta menganalisisnya; (4) mengidentifikasi kebenaran pernyataan, proses dan solusi; (5) merumuskan penjelasan, hipotesis dan konklusi, dan (6) menyusun pertimbangan yang bermaknaData hasil keefektifan bahan ajar selanjutnya dikonversi menjadi lima kategori keefektifan yaitu: sangat baik, baik, cukup baik, kurang baik, dan tidak baik dengan menggunakan formula pada Tabel 1. Selain menggunakan kategori keefektifan, bahan ajar juga dikatakan 
efektif apabila minimal $75 \%$ dari siswa mencapai kategori "baik" pada tes kemampuan berpikir kritis. Selanjutnya keefektifan bahan ajar diperkuat dengan menggunakan uji statistik. Uji statistik yang dimaksud adalah uji keefektifan bahan ajar dengan menggunakan uji Manova.

\section{Hasil dan Pembahasan}

Hasil penelitian ini meliputi tiga tahap utama, ketiga tahapan hasil penelitian tersebut diuraikan sebagai berikut:

\section{A. Tahap Studi Pendahuluan dan Desain Produk Awal}

Hasil dari penelitian ini adalah bahan ajar matematika SMP berbasis pendekatan scientific yang berorientasi pada kemampuan berpikir kritis matematis siswa. Bahan ajar yang dihasilkan pada materi kelas VIII SMP, berdasarkan kurikulum 2013 yang memuat Kompetensi Inti 3 dan 4 serta Kompetensi Dasar 3.6 dan 4.6. Berdasarkan KI dan KD tersebut, bahan ajar ini disusun menjadi 3 bab yang dijabarkan pada Tabel 3 berikut.

Tabel 3.

Penjabaran Topik pada Bahan Ajar Berbasis Scientific

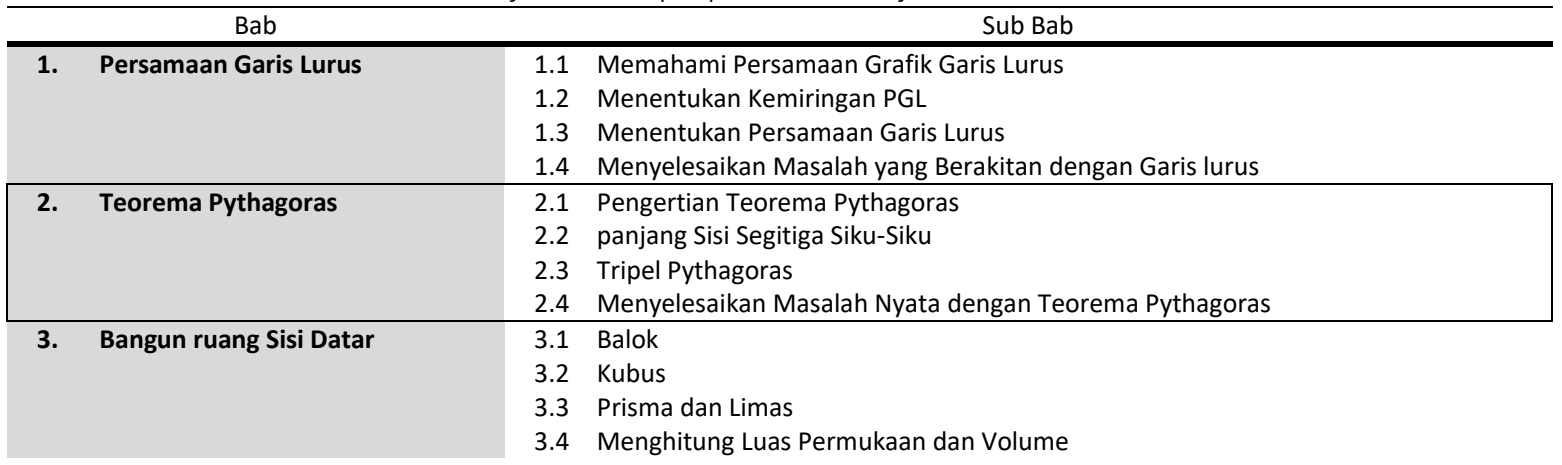

Pada setiap sub bab pada bahan ajar ini memuat secara utuh penjelasan materi di bagian awal, namun diberikan pula bagianbagian dari konsep yang harus di isi sendiri oleh siswa melalui beberapa langkah pengerjaan. Langkah tersebut akan menggiring siswa untuk lebih memahami apa yang disampaikan pada penjelasan materi di awal bagian. Selanjutnya setiap sub bab memuat langkah-langkah pembelajaran dengan pendekatan scientific yang diberikan melalui bagian-bagian yaitu: "Ayo kita amati bersama", "Ayo kita belajar bertanya" "Ayo kita mencoba menggali informasi bersama", Ayo kita belajar bernalar bersama" dan "Ayo kita berbagi informasi". Langkah-langkah scientific ini diberikan dikarenakan bahan ajar yang dikembangkan adalah bahan ajar berbasis scientific yang harus memuat lima pengalaman belajar pokok yaitu mengamati, menanya, mencoba, mengasosiasi/mengolah informasi dan mengkomunikasikan.

Desain bahan ajar yang telah dikembangkan dapat dilihat pada gambar berikut.

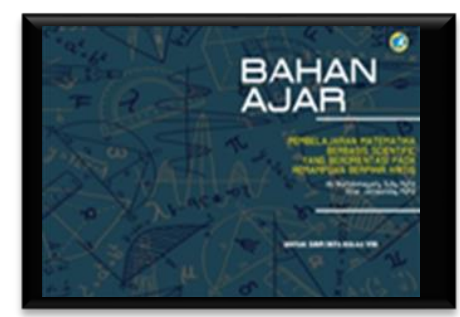

Gambar 1. Desain Bahan Ajar Berbasis

\section{Mosharafa: Jumal Pendidikan Matematika}


Secara umum hasil analisis pada tahap studi pendahuluan dan tahap desain produk awal dapat digambarkan pada Tabel 4 berikut.

Tabel 4.

Hasil Analisis Tahap Studi Pendahuluan dan Tahap Desain Produk Awal Bahan Ajar

\begin{tabular}{|c|c|c|}
\hline & Tahap Observasi & Tahap Desain Produk \\
\hline 1. & $\begin{array}{l}\text { Guru belum pernah melaksanakan pembelajaran } \\
\text { scientific karena masih menggunakan buku paket } \\
\text { kurikulum } 2006\end{array}$ & $\begin{array}{l}\text { Dibuat bahan ajar yang berbasis scientific yang disusun memuat } \\
\text { langkah-langkah pembelajaran berbasis scientif yang terdiri dari } \\
\text { bagian-bagian diantaranya: "Ayo kita amati bersama", "Ayo kita } \\
\text { belajar bertanya" "Ayo kita mencoba menggali informasi bersama", } \\
\text { Ayo kita belajar bernalar bersama" dan "Ayo kita berbagi informasi". } \\
\text { yang disusun dengan lebih komunikatif dan lebih mudah dipahami } \\
\text { siswa. Bahan ajar ini memuat } 3 \text { bab besar. }\end{array}$ \\
\hline 2. & $\begin{array}{l}\text { Siswa masih mengalami kesulitan dalam memahami } \\
\text { materi Teorema Pythagoras }\end{array}$ & $\begin{array}{l}\text { Disusun bahan ajar yang secara khusus mempelajari teorema } \\
\text { pythagoras yang berisi uraian materi, langkah-langkah kegiatan } \\
\text { scientific, contoh soal, latihan, dan evaluasi pembelajaran. }\end{array}$ \\
\hline 3. & $\begin{array}{l}\text { Guru dan siswa tidak menggunakan LKS sebagai bahan } \\
\text { ajar di sekolah }\end{array}$ & Disusun LKS khusus materi pythagoras \\
\hline 4. & $\begin{array}{l}\text { Guru belum pernah memberikan tes kemampuan } \\
\text { berpikir kritis matematis dan guru dan siswa belum } \\
\text { pernah menggunakan bahan ajar yang mendukung } \\
\text { terhadap perkembangan kemampuan berpikir kritis } \\
\text { matematis siswa }\end{array}$ & $\begin{array}{l}\text { Diberikan suatu konteks berupa ruang berlatih siswa untuk } \\
\text { mengembangkan kemampuan berpikir kritis matematis yang dapat } \\
\text { secara langsung dikerjakan siswa. Ruang berlatih ini difasilitasi pada } \\
\text { bagian "Ayo belajar berpikir kritis" pada tiap sub bab bahan ajar. }\end{array}$ \\
\hline
\end{tabular}

\section{B. Tahap Pengembangan Produk dan Evaluasi}

Tahap ini merupakan tahap pengembangan produk berupa bahan ajar matematika berbasis scientific. Bahan ajar yang telah dirancang dan dibuat pada tahap pendahuluan dan tahap desain produk awal disebut draft 1. Draft 1 selanjutnya dinilai kevalidan, kepraktisan dan keefektifannya yang diuraikan pada hasil uji coba produk berikut ini.

\section{Uji Validasi Ahli}

Kegiatan validasi bahan ajar dan instrumen penelitian melibatkan 4 validator yang memiliki keahlian tersendiri di bidangnya. Secara rinci hasil validasi bahan ajar yang dikembangkan dari tiap validator disajikan pada Tabel 5 berikut.
Tabel 5.

Hasil Analisis Kevalidan Bahan Ajar

\begin{tabular}{ccccc|}
\hline No & Validator & $\begin{array}{c}\text { Total } \\
\text { Skor }\end{array}$ & Interval & Kategori \\
\hline 1 & I & 150 & $x>142,8$ & Sangat Baik \\
\hline 2 & II & 153 & $x>142,8$ & Sangat Baik \\
\hline 3 & III & 160 & $x>142,8$ & Sangat Baik \\
\hline 4 & IV & 158 & $x>142,8$ & Sangat Baik \\
\hline & Jumlah & 621 & & \\
\hline & Rata-rata & 155,2 & $x>142,8$ & Sangat Baik \\
\hline
\end{tabular}

Hasil analisis kevalidan menunjukkan bahwa keempat validator memberikan penilaian terhadap bahan ajar yang telah dikembangkan yaitu valid dengan kategori sangat baik.

Selain penilaian kevalidan bahan ajar secara umum, ditunjukkan pula hasil penilaian kevalidan bahan ajar per komponen. Berikut hasil analisi kevalidan per komponen yang disajikan pada tabel 6 .

Tabel 6

Analisi kevalidan per komponen

\begin{tabular}{|lllll|}
\hline Komponen yang Dinilai & Validator & Jumlah & Interval & \multicolumn{1}{c}{ Kategori } \\
\hline Kelayakan Isi & I & 56 & $x>54,6$ & Sangat Baik \\
\cline { 2 - 5 } & II & 58 & $x>54,6$ & Sangat Baik \\
\cline { 2 - 5 } & III & 61 & $x>54,6$ & Sangat Baik \\
\cline { 2 - 5 } & IV & 60 & $x>54,6$ & Sangat Baik \\
\hline Kelayakan Pendekatan Scientific & I & 25 & $20,4<x<25,2$ & Baik \\
\cline { 2 - 5 } & II & 27 & $x>25,2$ & Sangat Baik
\end{tabular}




\begin{tabular}{|c|c|c|c|c|}
\hline & III & 28 & $x>25,2$ & Sangat Baik \\
\hline & IV & 28 & $x>25,2$ & Sangat Baik \\
\hline \multirow[t]{4}{*}{ Kelengkapan Penyajian } & 1 & 24 & $x>21$ & Sangat Baik \\
\hline & II & 22 & $x>21$ & Sangat Baik \\
\hline & III & 26 & $x>21$ & Sangat Baik \\
\hline & IV & 28 & $x>21$ & Sangat Baik \\
\hline \multirow[t]{4}{*}{ Kelayakan Kebahasanaan } & 1 & 23 & $x>21$ & Sangat Baik \\
\hline & II & 22 & $x>21$ & Sangat Baik \\
\hline & III & 25 & $x>21$ & Sangat Baik \\
\hline & IV & 24 & $x>21$ & Sangat Baik \\
\hline \multirow[t]{4}{*}{ Kelayakan Kegrafikan } & 1 & 22 & $x>21$ & Sangat Baik \\
\hline & $\|$ & 24 & $x>21$ & Sangat Baik \\
\hline & III & 20 & $17<x<21$ & Baik \\
\hline & IV & 22 & $x>21$ & Sangat Baik \\
\hline
\end{tabular}

Hasil analisis kevalidan per komponen menunjukkan bahwa rata-rata penilaian bahan ajar setiap validator berada pada kategori sangat baik.

\section{Uji Coba Terbatas}

Uji coba terbatas merupakan tahap awal dari uji coba produk terhadap siswa. Tahap uji coba ini melibatkan 9 siswa yang memiliki kemampuan akademik berbeda yakni 3 siswa berkemampuan tinggi, 3 siswa berkemampuan sedang dan 3 siswa berkemampuan rendah. Kesembilan siswa tersebut diminta membaca, mencermati, mengerjakan beberapa soal-soal pada bahan ajar kemudian diminta mengisi lembar penilaian bahan ajar yang telah disiapkan.

Adapun hasil penilaian dari kesembilan siswa tersebut dapat dilihat pada Tabel 7 berikut.

Tabel 7.

Hasil Penilaia Siswa Pada Uji Coba Terbatas

\begin{tabular}{cccc|}
\hline Kategori Siswa & $\begin{array}{c}\text { Rata-rata } \\
\text { skor }\end{array}$ & Interval & Kategori \\
\hline Tinggi & 44,33 & $40,8<x<50,4$ & Baik \\
\hline Sedang & 41 & $40,8<x<50,4$ & Baik \\
\hline Rendah & 41 & $40,8<x<50,4$ & Baik \\
\hline Rata-rata & 42,11 & $40,8<x<50,4$ & Baik \\
\hline
\end{tabular}

Penilaian siswa terhadap bahan ajar yang dikembangkan mendapatkan penilaian yang baik dari ke 9 siswa dengan kategori kemampuan berbeda. Dari semua kategori siswa, bahan ajar yang dikembangkan mendapatkan nilai pada kategori Baik. Artinya, ke 9 siswa tersebut menilai bahwa bahan ajar yang dikembangkan sudah cukup baik untuk dapat digunakan dalam proses pembelajaran di kelas pada pembelajaran materi Pythagoras.

\section{Uji Coba Lapangan}

Uji coba lapangan digunakan untuk mengetahui kepraktisan dan keefektifan bahan ajar yang dibuat. Uji kepraktisan dan keefektifan diuraikan sebagai berikut.

\section{a. Uji Kepraktisan Bahan Ajar}

Uji kepraktisan ini terdiri dari penilaian guru dan penilaian siswa terhadap bahan ajar yang dibuat.

Tabel 8.

Hasil Analisis Kepraktisan Bahan Ajar Oleh Guru

\begin{tabular}{lllll}
\hline No & Guru & $\begin{array}{l}\text { Total } \\
\text { skor }\end{array}$ & Interval & Kategori \\
\hline 1. & Guru I & 53 & $x>50,4$ & Sangat Baik \\
\hline 2. & Guru II & 51 & $x>50,4$ & Sangat Baik \\
\hline Jumlah & 104 & & \\
\hline Rata-rata & 52 & $x>50,4$ & Sangat Baik \\
\hline \multicolumn{6}{c}{ Berdasarkan } & & & \\
& & & & \\
& & & & \\
\end{tabular}

diketahui bahwa bahan ajar yang dihasilkan berada pada kategori sangat baik. 
1) Analisis data hasil penilaian siswa

Tabel 9.

Hasil Analisis Kepraktisan Bahan Ajar Oleh Siswa

\begin{tabular}{llll}
\hline Kelas & $\begin{array}{l}\text { Rata- Interval } \\
\text { Rata }\end{array}$ & \\
& & \\
\hline
\end{tabular}

Uji Coba 50,08

$40,8<x<50,4$

Baik

Berdasarkan Tabel 8 dan 9 di atas, dapat ketahui bahwa rata-rata hasil penilaian kepraktisan guru dan siswa terhadap bahan ajar yang dihasilkan rata-rata berada pada kategori Baik.

\section{b. Uji Keefektifan Bahan Ajar}

Keefektifan bahan ajar ini ditinjau dari hasil tes kemampuan berpikir kritis matematis. Tes ini dilakukan terhadap siswa pada kelas uji coba dan kontrol.

1) Analisis uji keefektifan bahan ajar

Penilaian keefektifan Bahan Ajar dapat dilihat dari hasil posttest kemampuan berpikir kritis siswa. Hasil pretes menunjukkan bahwa rata-rata ketuntasan belajar siswa adalah 0\% pada kedua kelas. Selanjutnya hasil posttest menunjukkan peningkatan terhadap kemampuan berpikir kritis siswa setelah dilakukan pembelajaran dengan menggunakan bahan ajar yang dibuat. Hal tersebut ditunjukkan dari analisis keefektifan bahan ajar pada Tabel

Tabel 10

Hasil Analisis Keefektifan Bahan Ajar

\begin{tabular}{lcccc}
\hline Kelas & $\begin{array}{l}\text { Banyak } \\
\text { siswa }\end{array}$ & Rata-rata & $\begin{array}{l}\text { Banyak siswa } \\
\text { yang minimal } \\
\text { berada pada } \\
\text { kategori baik }\end{array}$ & $\begin{array}{c}\text { Persentase } \\
\text { ketuntasan }\end{array}$ \\
\hline $\begin{array}{l}\text { Uji } \\
\text { Coba }\end{array}$ & 24 & 71,07 & 23 & $95,8 \%$ \\
\hline Kontrol & 24 & 63,92 & 21 & $87,5 \%$ \\
\hline
\end{tabular}

Tabel 10 di atas menunjukkan bahwa kedua bahan ajar telah memenuhi persentase kriteria ketuntasan minimal $75 \%$, oleh karena itu bahan ajar berbasis scientific dan buku paket pemerintah kedua nya dikatakan efektif ditinjau dari kemampuan berpikir kritis matematis siswa.

Selain hasil analisis keefektifan secara umum, disajikan pula hasil persentase banyaknya siswa yang minimal berada pada kategori baik untuk tiap indikator pada tabel 11 berikut.

Tabel 11.

Hasil Analisis Keefektifan Bahan Ajar Hasil Pretes Kemampuan Berpikir Siswa Per Indikator

\begin{tabular}{|c|c|c|c|c|c|c|c|c|c|c|}
\hline \multirow[t]{2}{*}{ No } & \multirow[t]{2}{*}{ Kelas } & \multirow[t]{2}{*}{$\begin{array}{l}\text { Banyak } \\
\text { siswa }\end{array}$} & \multicolumn{4}{|c|}{$\begin{array}{l}\text { Banyak siswa yang minimal berada } \\
\text { pada kategori baik per indicator }\end{array}$} & \multicolumn{4}{|c|}{ Persentase ketuntasan } \\
\hline & & & A & B & $C$ & D & A & B & C & D \\
\hline 1. & Uji coba & 24 & 0 & 0 & 0 & 0 & $0 \%$ & $0 \%$ & $0 \%$ & $0 \%$ \\
\hline 2. & Kontrol & 24 & 0 & 0 & 0 & 0 & $0 \%$ & $0 \%$ & $0 \%$ & $0 \%$ \\
\hline
\end{tabular}

Tabel 12.

Hasil Analisis Keefektifan Bahan Ajar Hasil Postest Kemampuan Berpikir Siswa Per Indikator

\begin{tabular}{lllllllllll}
\hline No & Kelas & $\begin{array}{l}\text { Banyak } \\
\text { siswa }\end{array}$ & \multicolumn{6}{l}{$\begin{array}{l}\text { Banyak siswa yang minimal } \\
\text { berada pada katgeori baik per } \\
\text { indicator }\end{array}$} & \multicolumn{2}{l}{ Persentase ketuntasan } \\
\cline { 3 - 13 } & & A & B & C & D & A & B & C & D \\
\hline 1. & Uji coba & 24 & 23 & 22 & 21 & 22 & $95,8 \%$ & $91,7 \%$ & $87,5 \%$ & $91,7 \%$ \\
\hline 2. & Kontrol & 24 & 20 & 18 & 19 & 19 & $83,3 \%$ & $75 \%$ & $79,2 \%$ & $79,2 \%$ \\
\hline
\end{tabular}

Keterangan:
A : Indikator Mengidentifikasi kebenaran pernyataan, proses dan solusi
$\mathrm{B}$ : Indikator Menganalisis, dan menjelaskan pertanyaan, jawaban dan argumen
C : Indikator Mengidentifikasi kebenaran pernyataan, proses dan solusi
$\mathrm{D}$ : Indikator Merumuskan penjelasan, hipotesis dan konkulsi 
Berikut adalah grafik pretest, postest dan persentase ketuntasan belajar siswa terhadap kemampuan berpikir kritis matematis pada kelas uji coba dan kelas kontrol.

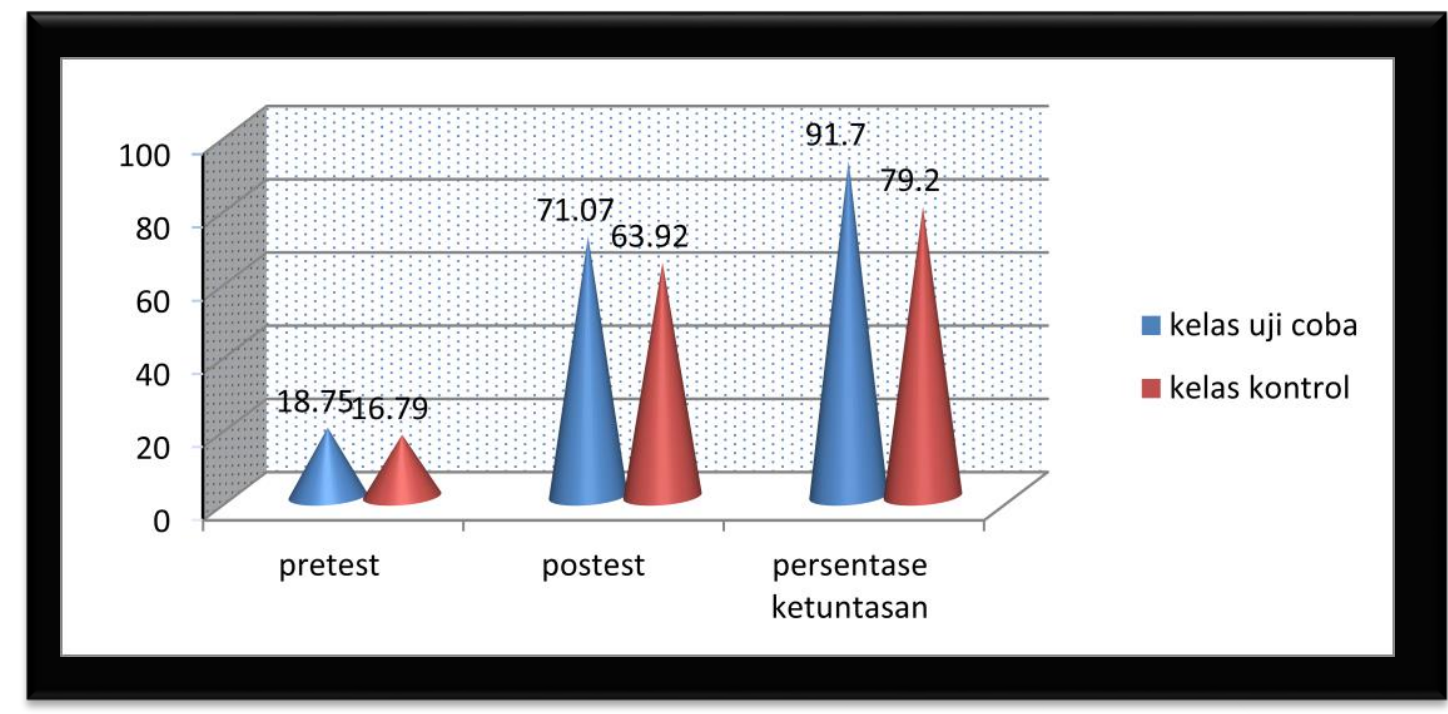

Gambar 2. Grafik Pretest, postest dan persentase ketuntasan belajar siswa terhadap kemampuan berpikir kritis matematis

Berdasarkan grafik di atas, dapat diketahui bahwa pada nilai terdapat perbedaan cukup siginifikan antara nilai akhir hasil pembelajaran dengan bahan ajar berbasis scientific pada kelas uji coba dan kelas kontrol. Begitu pula pada persentase ketuntasan menunjukkan nilai yang cukup jauh sebesar 12,5 \% lebih besar kelas uji coba daripada kelas kontrol.

2) Analisis uji perbedaan keefektifan bahan ajar

Uji perbedaan keefektifan dilakukan untuk mengetahui ada tidaknya perbedaan keefektifan bahan ajar ang digunakan antara kelas uji coba dan kelas kontrol. Uji perbedaan keefektifan ini menggunakan uji multivariat Hotteling's Trace. Analisis dilakukan pada taraf signifikansi 0,05 dengan kriteria uji tolak $\mathrm{H}_{0}$ jika nilai sig $<0.05$.
Hasil uji multivariat perbedaan keefektifan dapat dilihat dari Tabel 13 berikut.

Tabel 13.

Hasil Uji Multivariat Perbedaan Keefektifan Bahan

\begin{tabular}{cccc}
\multicolumn{4}{c}{ Ajar } \\
\hline & Effect & $F$ & Sig. \\
\hline Kelas & Hotteling's Trace & $6.834^{\mathrm{a}}$ & 0,003
\end{tabular}

Berdasarkan Tabel 13 di atas, dapat diketahui signifikansi hasil uji multivariat adalah 0,003 $<0,005$. Hal ini berarti $\mathrm{H}_{0}$ di tolak dan $\mathrm{H}_{1}$ diterima. Dengan demikian dapat disimpulkan bahwa terdapat perbedaan keefektifan pembelajaran kela uji coba yang menggunakan bahan ajar berbasis scientific dengan pembelajaran kelas kontrol yang menggunakan buku paket biasa ditinjau dari kemampuan berpikir kritis matematis siswa. 
3) Analisis uji perbandingan keefektifan bahan ajar

Uji perbandingan keefektifan dilakukan untuk mengetahui bahan ajar mana yang lebih efektif digunakan siswa terhadap kemampuan berpikir kritis siswa. Uji keefektifan yang digunakan adalah uji univariat. Analisis dilakukan pada taraf signifikansi 0,05 dengan kriteria uji tolak $\mathrm{H}_{0}$ jika nilai sig $<0.05$.

Berikut adalah hasil uji univariat untuk uji perbandingan keefektifan bahan ajar ditinjau dari kemampuan berpikir kritis siswa.

Tabel 14

Hasil Uji Univariat Perbandingan Keefektifan Bahan Ajar

\begin{tabular}{llll}
\hline Posstest & Mean square & F & Sig. \\
\hline $\begin{array}{l}\text { Between } \\
\text { Group }\end{array}$ & 833.333 & 13.731 & 0.001 \\
& & &
\end{tabular}

Berdasarkan Tabel 14 di atas, nilai signifikansi adalah 0,001<0,005. Artinya bahwa $\mathrm{H}_{0}$ ditolak dan $\mathrm{H}_{1}$ diterima. Dengan demikian dapat disimpulkan bahwa pembelajaran dengan menggunakan bahan ajar berbasis scientific lebih efektif dibandingkan pembelajaran dengan menggunakan buku paket biasa ditinjau dari kemampuan berpikir kritis matematis siswa.

Kepraktisan bahan ajar dibuktikan berdasarkan hasil penilaian siswa pada tahap uji coba terbatas, uji coba lapangan serta hasil observasi pelaksanaan pembelajaran menggunakan bahan ajar yang dibuat. Berdasarkan analisis hasil penilaian baik guru maupun siswa, diperoleh hasil bahwa bahan ajar yang telah dibuat mendapat penilaian dengan kategori "baik". Penilaian tersebut diataranya terkait tampilan bahan ajar dan kemudahan dalam menggunakan bahan ajar yang dibuat serta respon siswa terhadap efek penggunaan bahan ajar dalam belajar matematika. Hasil analisis menunjukkan ketiga aspek tersebut mendapat penilaian rata-rata "baik" oleh guru dan siswa.

Keefektifan bahan ajar dapat dilihat dari hasil uji coba lapangan melalui tahap tes kemampuan berpikir kritis matematis. Hasil uji coba lapangan menunjukkan bahwa persentase banyaknya siswa yang minimal berada pada kategori baik setelah menggunakan bahan ajar yang dikembangkan adala 95,8\% dari sebelumnya $0 \%$ pada kelas uji coba. Keadaan ini dikarenakan sebelum pembelajaran siswa belum memahami soal-soal yang berkaitan dengan kemampuan berpikir kritis. Persentase ketuntasan posttest telah memenuhi kriteria minimal 75\% sehingga dapat dikatakan bahwa bahan ajar yang dikembangkan efektif ditinjau dari kemampuan berpikir kritis. Demikian pula disimpulkan bahwa buku paket biasa yang digunakan pada kelas kontrol dikatakan efektif ditinjau dari kemampuan berpikir kritis karena memenuhi kriteria minimal persentase ketuntasan.

Hasil uji perbandingan keefektifan yang dilakukan menyimpulkan bahwa bahan ajar berbasis scientific lebih efektif daripada buku paket biasa ditinjau dari kemampuan berpikir kritis siswa. Hal ini dikarenakan bahan ajar yang dibuat telah dirancang sedemikian rupa berdasarkan tahapan pembelajaran scientific dalam upaya pengembangan kemampuan berpikir kritis. Seperti pernyataan Hope (2013) yang menyatakan bahwa 
penerapan scientific adalah untuk mengeksplorasi ilmu pengetahuan kepada siswa dalam kegiatan mengamati, menanya, memprediksi, mencoba, meringkas dan berbagi hasil. Melalui tahapan kegiatan tersebut siswa dapat melatih berpikir logis, sistematis dan ilmiah yang pada akhirnya akan mampu meningkatkan kemampuan berpikir kritisnya. Pada bahan ajar ini juga dibuat soal-soal khusus untuk mengolah kemampuan berpikir kritis, sedangkan pada buku paket matematika biasa tidak ada. Setiap langkah dalam pembelajaran scientific menuntut siswa untuk dapat berpikir kritis terhadap masalah matematika dan soal-soal matematika yang disajikan. Selain dikarenakan tahapan belajar yang disajikan pada bahan ajar yang jauh lebih bermakna, bahan ajar berbasis scientific juga dipelajari siswa dengan rasa senang karena siswa dapat terlibat dalam proses penyelidikan dan pembelajaran secara langsung serta tidak akan membosankan. Sedangkan pada bahan ajar buku paket biasa tidak. Sesuai dengan pernyataan Kemendikbud (2013) bahwa pendekatan scientific menjadikan pembelajaran lebih aktif dan tidak membosankan. Dengan demikian jelas bahwa bahan ajar berbasis scinetific pada kelas uji coba akan lebih efektif daripada buku paket matematika biasa pada kelas kontrol ditinjau dari kemampuan berpikir kritis matematis siswa.

\section{Penutup}

Kesimpulan dari penelitian ini antara lain Bahan ajar matematika berbasis scientific yang dibuat telah memenuhi kriteria valid, praktis dan efektif ditinjau dari kemampuan berpikir kritis matematis siswa. Selain itu, Respon siswa terhadap bahan ajar matematika berbasis scientific adalah positif.

Berdasarkan hasil penelitian, terdapat beberapa saran, diantaranya adalah guru diharapkan melakukan perubahan pola pikir terlebih dahulu dalam memahami kurikulum 2013 sehingga dapat menyesuaikan setiap langkah scientific dengan baik. Selain itu, alam pengembangan bahan ajar diperlukan kajian literatur yang cukup memadai sehingga bahan ajar yang dihasilkan akan optimal. Selanjutnya, diharapkan untuk dapat mengembangkan bahan ajar matematika tidak hanya pada satu materi namun untuk beberapa materi pada satuan semester.

\section{DAFTAR PUStaka}

Azwar, S. (2015). Tes Prestasi: fungsi pengembangan pengukuran prestasi belajar (edisi kedua). Yogyakarta: Pustaka Pelajar

Anitasari, E. (2015). Efektivitas pembelajaran matematika dengan pendekatan scientific berbasis teori kecerdasan majemuk ditinjau dari kemampuan berpikir kritis matematis dan kemandirian belajar siswa smp kelas VIII. Thesis UNY

Borg, W. R \& Gall, M. D. (1983). Educational Research: An Intriduction $\left(4^{\text {th }}\right.$ ed). New York City: Longman.

Depdiknas. (2008). Panduan Pengembangan Bahan Ajar.

Fisher, A. (2009). Berpikir Kritis: Sebuah Pengantar. Jakarta: Erlangga.

Hope, Gerde. K dkk. (2013). Using the Scientific Method to Guide Learning: An Integrated Approach to Early 
Childhood Curriculum. Early Childhood Educ Journal (Vol 41 No 5) Jumaisyaroh, T. E.E. (2014). Peningkatan Kemampuan Berpikir Kritis Matematis Dan Kemandirian Belajar Siswa SMP Melalui pembelajaran Berbasis Masalah. JURNAL KREANO, ISSN: 2086-2334 Diterbitkan Oleh Jurusan Matematika FMIPA UNNES Volume 5 Nomor 2 Bulan Desember Tahun 2014

Kemendikbud. (2013). Permendikbud Nomor 65 Tahun 2013 tentang Standarsan Proses. Jakarta: Kemendikbud.

Maryati, I. (2018). Penerapan Model Pembelajaran Berbasis Proyek dalam Materi Statistika Kelas VIII Sekolah Menengah Pertama. Mosharafa: Jurnal Pendidikan Matematika, 7(3), 467-476.

Niveen, N. (1999). Computer support for curriculum developers: A study on the potential of computer support in the domain of formative evaluation. Doctoral dissertation, University of Twente, Enschede, The Netherlands.

Ramziah, S. (2016). Peningkatan Kemampuan Representasi Matematis Siswa Kelas X2 SMAN 1 Gedung Meneng Menggunakan Bahan Ajar Matriks Berbasis Pendekatan Saintifik. Mosharafa: Jurnal Pendidikan Matematika, 5(2), 138-147.

Razak, F. \& Kamaruddin, R. (2018). Pengaruh Sikap Ilmiah Siswa terhadap Hasil Belajar Materi Bangun Ruang Siswa Kelas VIII SMP Negeri 3 Minasatene. Mosharafa: Jurnal Pendidikan Matematika, 7(1), 138-147.

Santrock, John W. (2007).

Perkembangan Anak. Jakarta.

Erlangga.

Soeprapto. (2001). Membuat Manusia

Berpikir Kreatif dan Inovatif. Bandung: Nuansa
Syahbana, A. (2012). Peningkatan

Kekmampuan Berpikir Kritis

Matematis Siswa SMP Melalui

Pendekatan Contextual Teaching

and Learning. Jurnal

Edumatica(Online), 2(1).

\section{Riwayat Hidup Penulis}

lik Nurhikmayati, S.Si., M.Pd.

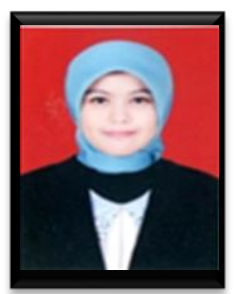

Lahir di Majalengka, 17 April 1987. Dosen pendidikan matematika di Universitas Majelangka. Study S1 pada Program Studi Matematika, UPI Bandung tahun 2009. Study 52 pada Program Studi Pendidikan Matematika

PascaSarjana Universitas UPI Tahun 2012

\section{Gilar Jatisunda, M.Pd.}

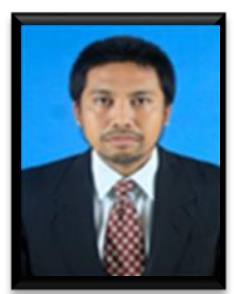

Lahir di Majalengka, 21 November 1985. Dosen pendidikan matematika di Universitas Majelangka. Study S1 pada Program Studi Pendidikan Matematika, Universitas Swadaya Gunung Jati Cirebon tahun 2010. Study s2 pada Program Studi Pendidikan Matematika PascaSarjana UPI Tahun 2013. 